\title{
Improvement of the Performance of PV System with CUK Converter by MPPT Technology
}

\author{
Mrutyunjay Das \\ Research scholar \\ School of Electrical Engineering, \\ KIIT University
}

\author{
C.K. Panigrahi, PhD \\ Professor \& Dean \\ School of Electrical Engineering, \\ KIIT University
}

\author{
M.K. Moharana, $\mathrm{PhD}$ \\ Associate Professor \\ School of Elektrical Engineering, \\ KIIT University
}

\begin{abstract}
Maximum Power Point Tracking (MPPT) algorithms are used in PV system to maximize the output power. In this paper MPPT algorithm is implemented using Ćuk converter in PV system. The dynamics of photovoltaic system is simulated at different solar irradiance and cell temperature and is validated by using Perturb and Observe ( $\mathrm{P} \& \mathrm{O})$ method in Maximum Power Point Tracking algorithm.
\end{abstract}

\section{Keywords}

Cuk Converter, MPPT (Maximum Power Point Tracking), P\&O algorithm.

\section{INTRODUCTION}

The main objective of a solar photovoltaic system is to convert solar energy in to electrical energy. For this conversion to take place in an efficient and effective manner different types of converters with a suitable control strategy are used. Among different types of converters used in solar PV system, both Cuk and buck-boost converters can have either higher or lower output voltage compared with the input voltage. Although the buck-boost configuration is simple and cheaper than the Cuk configuration, it has some disadvantages, such as discontinuous input current, high peak currents in power components, and poor transient response, which makes it less efficient. On the other hand, with the use of Cuk converter the switching losses can be reduced and hence the efficiency can be increased. The Cuk converter can also provide a smooth output-current characteristic due to the presence of an inductor in the output stage. Thus, the Cuk configuration is a most suitable converter to be employed in designing the MPPT. Figs. 1 and 2 show a Cuk converter and its operating modes, which is used as the interface between the power stage of the PV module and the load.

\section{PROBLEM FORMULATION}

A non-isolated Cuk converter comprises two inductors, two capacitors, a switch (usually a transistor), and a diode. (Figure 1). As it acts as an inverting converter, the output voltage is negative with respect to the input voltage. The capacitor is used to transfer energy and is connected alternately to the input and to the output of the converter via the commutation of the transistor and the diode (figures 2).

\section{SOLUTION METHODOLOGY}

The two inductors $\mathrm{L}_{1}$ and $\mathrm{L}_{2}$ are used to convert the input voltage source $\left(\mathrm{V}_{\mathrm{g}}\right)$ and the output voltage source $\left(\mathrm{C}_{2}\right)$ respectively into current sources. For a small time interval an inductor can be considered as a current source as it maintains a constant current. This conversion is necessary because if the capacitor were connected directly to the voltage source, the current would be limited only by the parasitic resistance, resulting in high energy loss. Charging a capacitor with a current source (the inductor) prevents resistive current limiting and its associated energy loss.

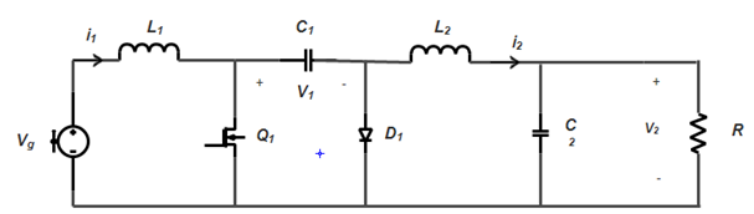

Figure-1: Electrical circuit of the Cuk Converter

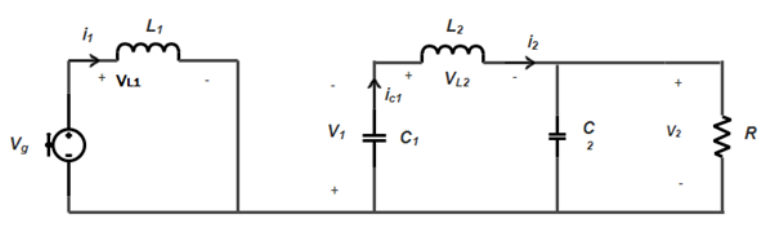

Figure-2(a): Cuk Converter with switch ON

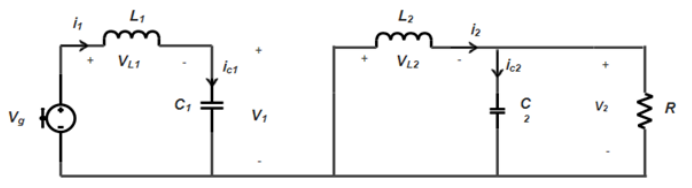

Figure-2(b): Cuk Converter with switch OFF

The complete operation of the converter is divided in to two modes of operation. During mode 1, the transistor switch is closed, which rises the current through inductor $\mathrm{L}_{1}$. During this period voltage of capacitor $C_{1}$ makes the diode reverse bias and turns it off. The capacitor $\mathrm{C}_{1}$ discharges through $\mathrm{C}_{2}, \mathrm{~L}_{2}$ and load.

During mode 2, the transistor switch is made open which makes the diode $\mathrm{D}$ to be forward biased. During this period capacitor $\mathrm{C}_{1}$ is charged. The energy stored in the inductor $\mathrm{L}_{1}$ is transferred to the load. The synchronous switching action is being provided by the diode $\mathrm{D}$ and the switch.

The equations for the switch conduction mode are as follows.

$V_{L 1}=V_{g}$

$V_{L 2}=V_{1}-V_{2}$

$I_{C 1}=I_{2}$

$I_{C 2}=I_{2}-\left(V_{2} / R\right)$

The relations between output and input currents and voltages are given in the following:

$V_{L 1}=V_{g}-V_{1}$

$V_{L 2}=V_{2}$

$I_{C 1}=I_{1}$

$I_{C 2}=I_{2}-\left(V_{2} / R\right)$ 
Some analyses of Cuk converter specifications are provided in, and a comparative study on different schemes of switching converters is presented in the literature.

$\frac{V_{0}}{V_{\text {in }}}=\frac{D}{1-D}$

$\frac{I_{\text {in }}}{I_{0}}=\frac{D}{1-D}$

The power circuit of the proposed system consists of a Cuk converter and a gate drive, and the control of the switching is done using the control circuit. The control tasks involve measuring the analog voltage and current of the PV module using current and voltage sensors, convert them to digital using an ADC, process the obtained information in a microcontroller, then compare them with the predefined values to determine the next step, revert the PWM to the gate drive, and hence control the switching of IGBTs. The control loop frequently happens with respect to the sampling time, and the main program continues to track the MPP.

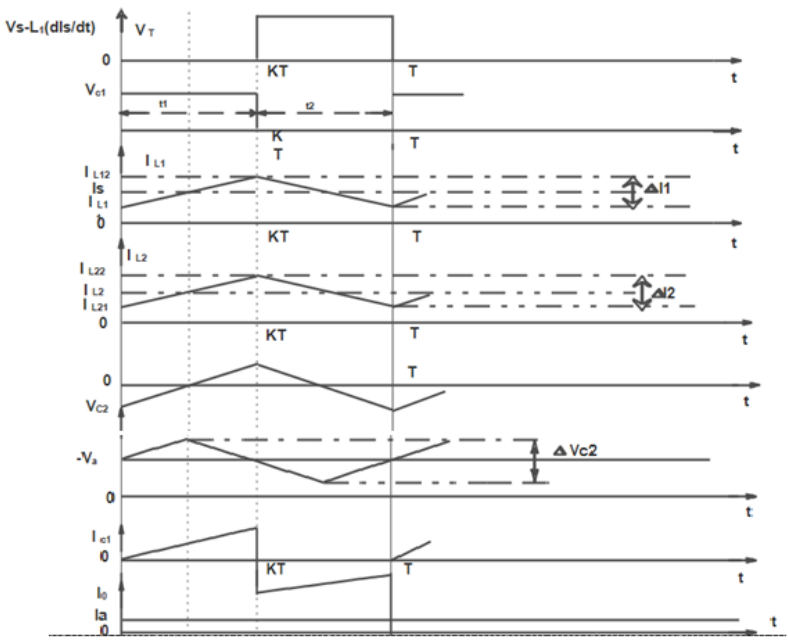

Figure-3: waveform of Cuk Converter

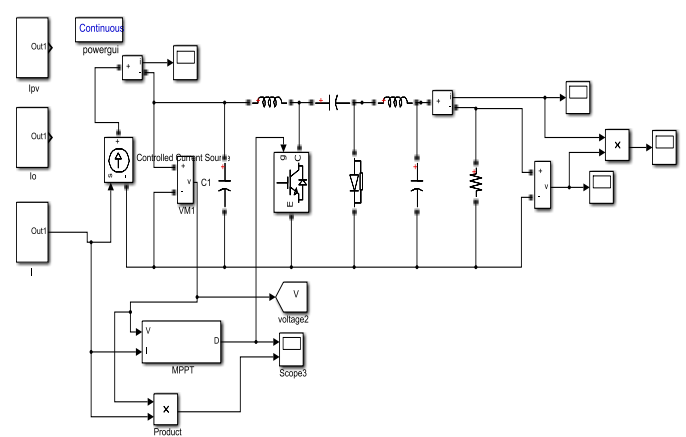

Figure-4: Simulation of PV model with Cuk converter

\section{RESULT}

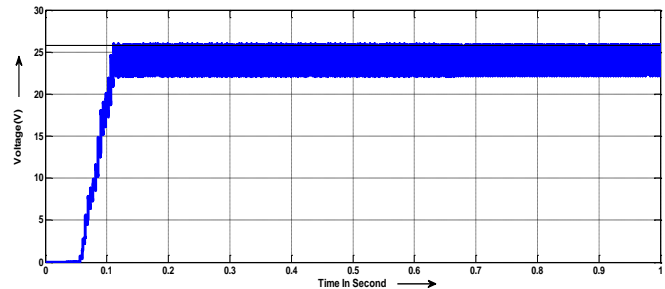

Figure-5: Output voltage curve of cuk converter with MPPT

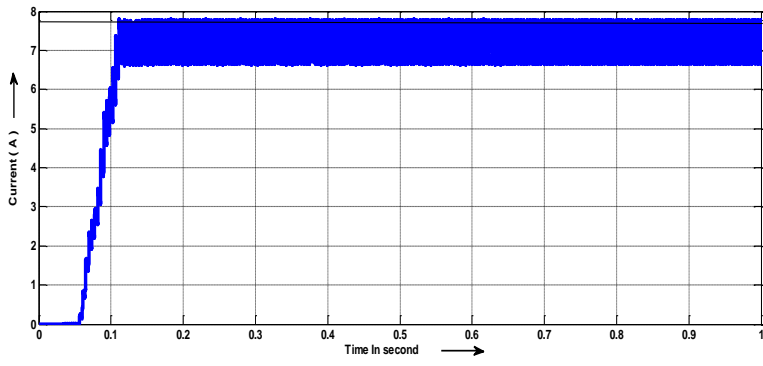

Figure-6: Output current curve of cuk converter with MPPT

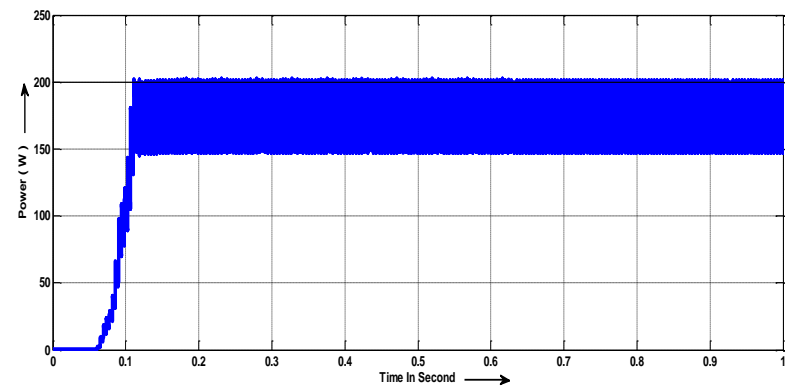

Figure-7: Output Power curve of cuk converter with MPPT

The following simulation results of voltage, current and power curve at irradiance $800 \mathrm{w} / \mathrm{m}^{2}$.

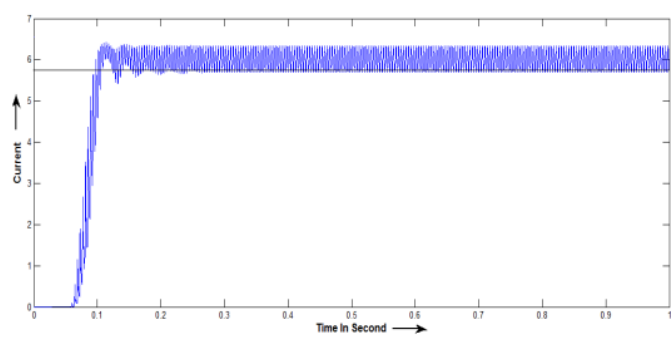

Figure-8: Output current curve of cuk converter with MPPT at $800 \mathrm{w} / \mathrm{m}^{2}$ irradiance

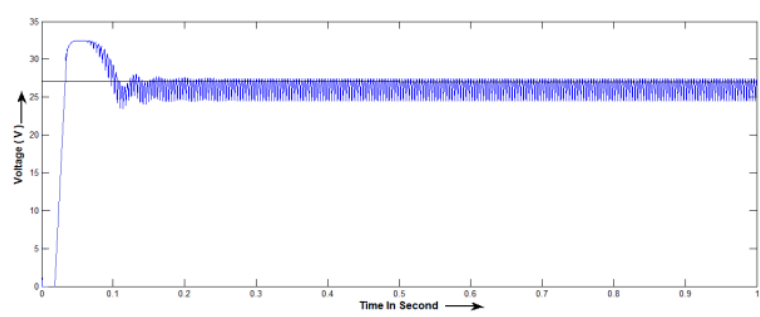

Figure-9: Output Voltage curve of cuk converter with MPPT at $800 \mathrm{w} / \mathrm{m}^{2}$ irradiance

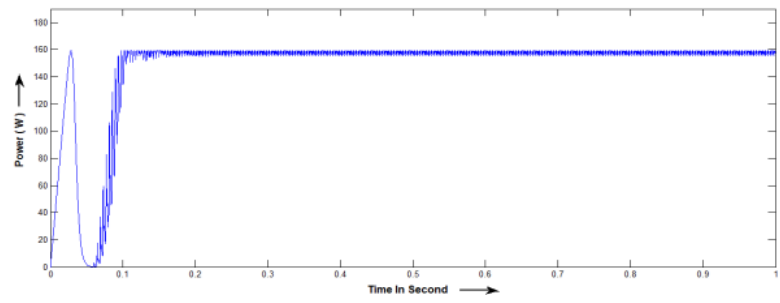

Figure-10: Output Power curve of cuk converter with MPPT at $800 \mathrm{w} / \mathrm{m}^{2}$ irradiance 
The following simulation results of voltage, current and power curve at irradiance $600 \mathrm{w} / \mathrm{m}^{2}$.

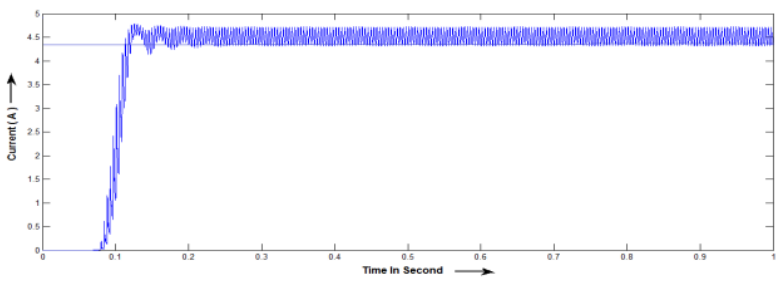

Figure-11: Output Current curve of Cuk converter with MPPT at $600 \mathrm{w} / \mathrm{m}^{2}$ irradiance

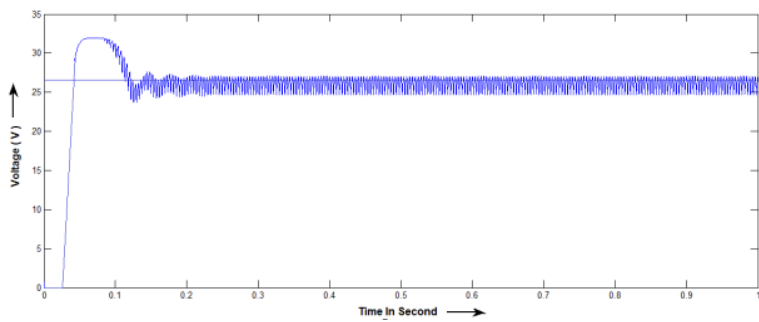

Figure-12: Output Voltage curve of Cuk converter with MPPT at $600 \mathrm{w} / \mathrm{m}^{2}$ irradiance

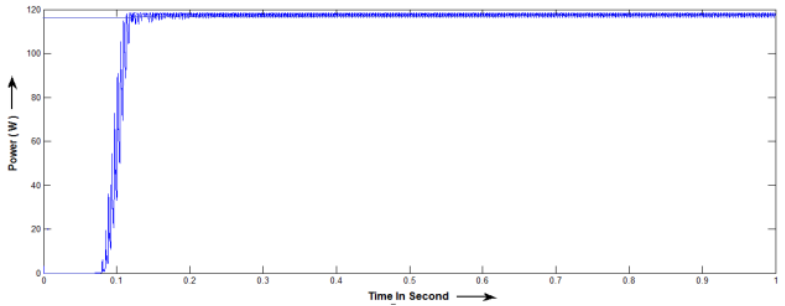

Figure-13: Output Power curve of Cuk converter with MPPT at $600 \mathrm{w} / \mathrm{m}^{2}$ irradiance

The following simulation results of voltage, current and power curve at irradiance $400 \mathrm{w} / \mathrm{m}^{2}$.

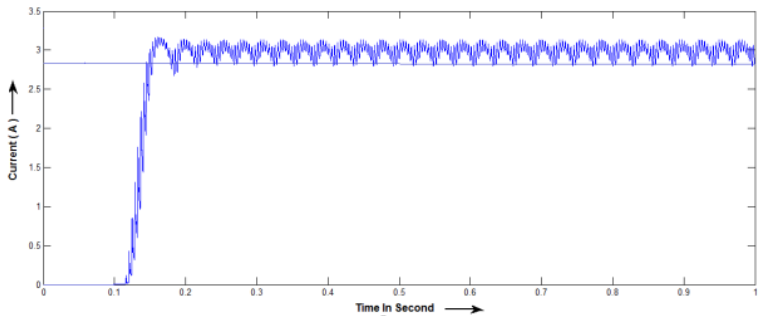

Figure-14: Output Current curve of Cuk converter with MPPT at $400 \mathrm{w} / \mathrm{m}^{2}$ irradiance

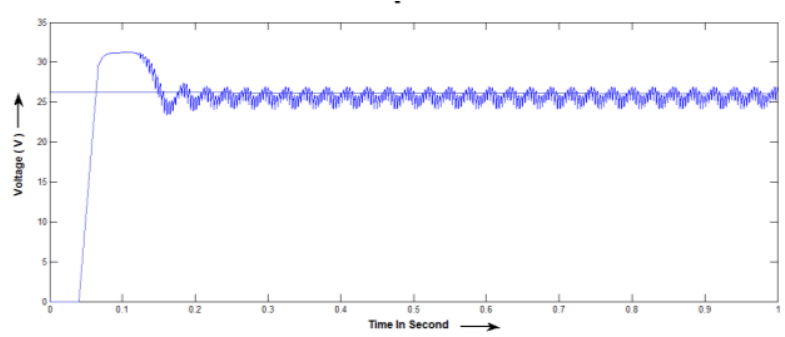

Figure-15: Output Voltage curve of Cuk converter with MPPT at $400 \mathrm{w} / \mathrm{m}^{2}$ irradiance

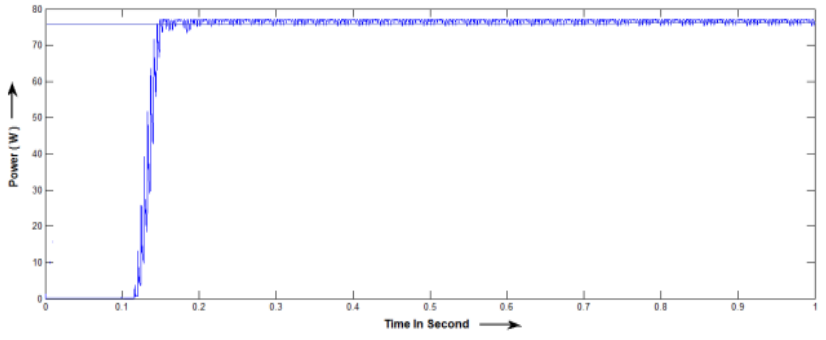

Figure-16: Output Voltage curve of Cuk converter with MPPT at $400 \mathrm{w} / \mathrm{m}^{2}$ irradiance

\section{CONCLUSION}

The PV system has been controlled to extract the maximum power from the available insolation. The output voltages and currents of the Cuk converter are also analyzed through the software platform in different irradiance level. From the simulation results it is observed that with the use of MPPT system with Cuk converter increases the output voltage, current and power. Also the output becomes stable with Cuk converter. The $\mathrm{P} \& \mathrm{O}$ algorithm used in the system gives the optimum duty cycle to extract the maximum power from the PV system.

\section{ACKNOWLEDGMENT}

The authors would like to thank authorities, KIIT University, Bhubaneswar, Odisha, India for giving opportunities to do research work in the laboratories.

\section{REFERENCES}

[1] D. W. Hart "Power Electronics" first Edition., New York: 2011.

[2] M. Kasper, D. Bortis, T. Friedli and J. W. Kolar, "Classification and Comparative Evaluation of PV Panel Integrated DC-DC Converter Concepts", IEEE Power Electronics and Motion Control conference (EPE/PEMC), pp.LS1e.4-1-LS1e.4-8, 2012.

[3] Zameer Ahmad and S.N. Singh, "Extraction of the Internal Parameters of Solar Photovoltaic Module by Developing Matlab / Simulink Based Model", International Journal of Applied Engineering Research, ISSN 0973-4562 Vol.7 No.11, 2012.

[4] S. Sheik Mohammed, "Modeling and Simulation of Photovoltaic Module using MATLAB/Simulink", International Journal of Chemical and Environmental Engineering Volume 2, No.5, October 2011.

[5] Azadeh Safari and Saad Mekhilef, "Simulation and Hardware Implementation of Incremental Conductance MPPT with Direct Control Method Using Cuk Converter", IEEE Transaction on Industrial Electronics, Vol.58, no.4. 2011.

[6] C. Larbes, S.M.Ait Cheikh, T. Obeidi, A. Zerguerras, "Genetic Algorithms Optimized Fuzzy Logic Control for The Maximum Power Point Tracking in Photovoltaic System", Elsevier, Renewable Energy, vol.34, pp.20932100, Feb 2009.

[7] Cameron. C.P., Boyson. W.E., Riley, D.M., "Comparison of PV System Performance-Model Predictions with Measured PV System Performance", 33rd IEEE Photovoltaic Specialists Conference, 2008. 
[8] Safari, A; Mekhilef, S "Simulation and Hardware Implementation of Incremental Conductance MPPT with Direct Control Method Using Cuk Converter," Industrial Electronics, IEEE Transactions on, vol.PP, no.99, pp.1-1, Odoi: 10.1109/TIE.2048834, 2010.

[9] Srushti R. Chafle1, Uttam B. Vaidya, "Incremental Conductance MPPT Technique for PV System", International Journal of Advanced Research in Electrical, Electronics and Instrumentation Engineering, Vol. 2, Issue 6, June 2013

[10] Y. Yusof, S. H. Sayuti, M. Abdul Latif, M. Z. C. Wanik, "Modeling and Simulation of Maximum Power Point Tracker for Photovoltaic System," Proceedings of Power and Energy Conference, (PECon 2004), pp. 88- 93, 29-30 Nov. 2004
[11] Kuo,Y. Liang,T. \& Chen,J. "Novel Maximum-PowerPoint-Tracking Controller for Photovoltaic Energy Conversion System". IEEE Transactions on Industrial Electronics, Volume 48, Issue 3, Page(s):594 - 601, June 2001.

\section{AUTHOR PROFILE}

Mrutyunjay Das was born in Mayurbhanj, Odisha, India. He received his Bachelor's degree (Electrical Engineering) from The Institution of Engineers, (India) in 1991 and received his M.Tech (Power Electronics and Drives) from S'O'A University, Bhubaneswar, India in 2009. His area of interests power Electronics, Photo voltaic energy system. He is currently working as Lecturer in Electrical Engineering at Seemanta Engineering College, Jharpokharia, Mayurbhanj, Odisha, India. 